\title{
Criminal personality in a trained elite military and assassination
}

DOI: $10.46932 / \operatorname{sfjdv2n2-190~}$

Received in: March 1st, 2021

Accepted in: May 30th, 2021

\author{
Dr. Bernat-Noël Tiffon Nonis \\ Universitat Abad Oliba-CEU. Calle de Bellesguard, no30. 08022 Barcelona (Spain). \\ E-mail: btiffonn@uao.es
}

\section{RESUME}

This article aims to explain the base personality traits in a case of murder perpetrated by a subject who developed professional activities in the elite military field (he was a sniper specialized in special missions abroad), what repercussions or juridical-legal consequences it entailed for the crime of murder (a civilian) that he perpetrated, and the sentence issued for that purpose.

\section{THE CASE:}

Thus, it is a 24-year-old male, a native of Eastern Countries, of single marital status, and an academic level equivalent to secondary studies. He was adopted from the age of 8 into a Spanish family. It should be noted that the reported person had a history of mental dysfunction during his childhood, which was the result of experienced adversities:

- He was subjected to domestic violence within his biological family until the age of 8 years (approx.) exercised by his biological father.

- He was an object of violence within the boarding school for which he was admitted as a result of the domestic violence exercised by his father against his own family and wife (Gender Violence).

- Problems of low school motivation during his student period within the framework of Spanish education once adopted by his host family.

- Behavioral problems arising from his association with a Neo-Nazi group.

- These last two circumstances, says the informed, motivated that he could be diagnosed with Attention Deficit Hyperactivity Disorder (ADHD), but that such point was not confirmed due to the lack of clinical history available.

- $\quad$ Father (biological) deceased due to chronic alcohol consumption.

When the events were perpetrated (murder at the victim's home) as a result of an important and heated discussion with a neighbor who was stabbed 30 times, the informed person was working as a professional soldier as a Soldier-Sniper in La Legión (from a country of Western Europe), belonging to a section specialized in Anti-Terrorism. 


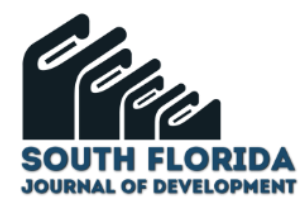

The informed person was admitted to a Madrid Penitentiary Center for a crime against independent human life.

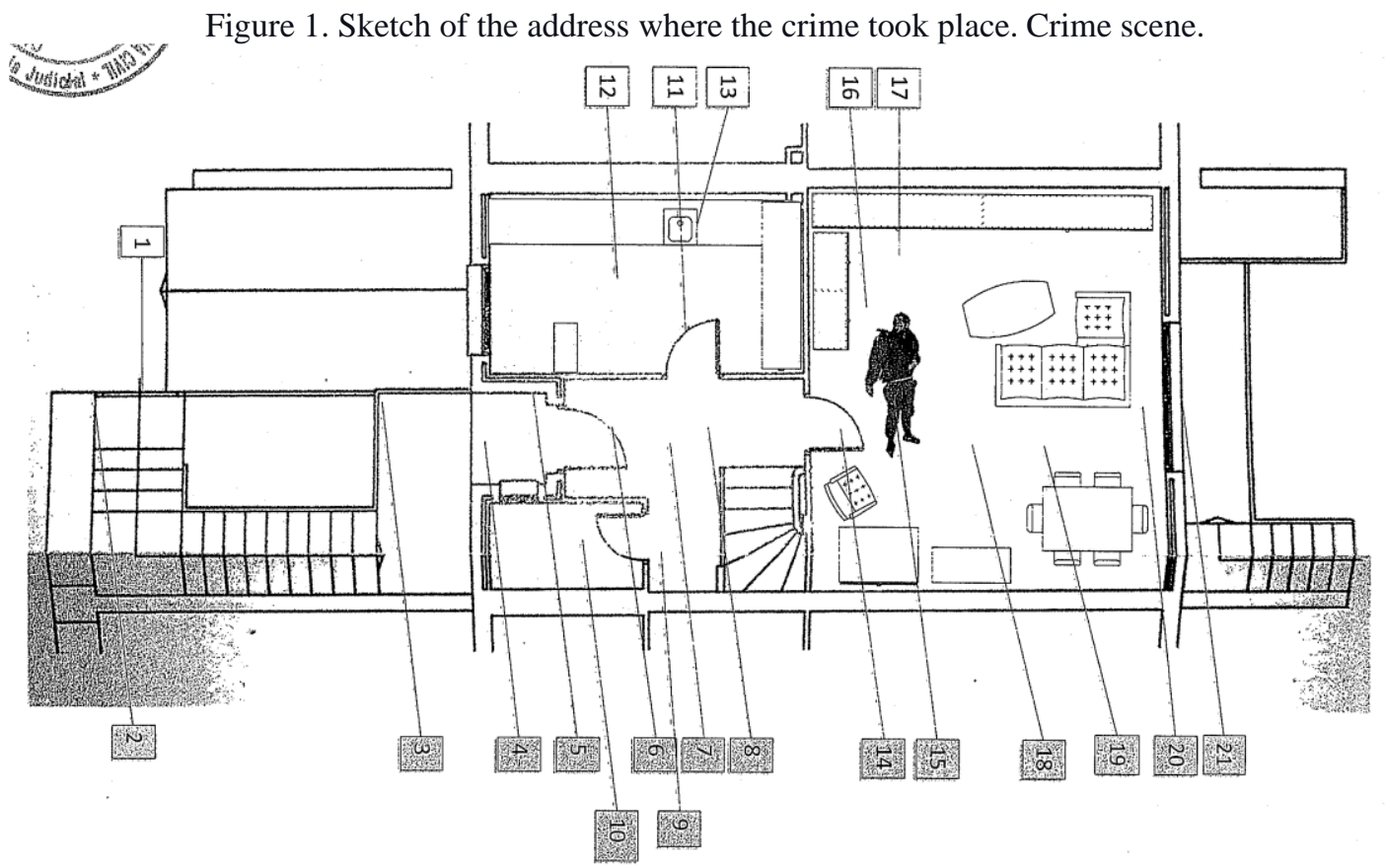

Figure 2: White weapon used for the perpetration of the crime.

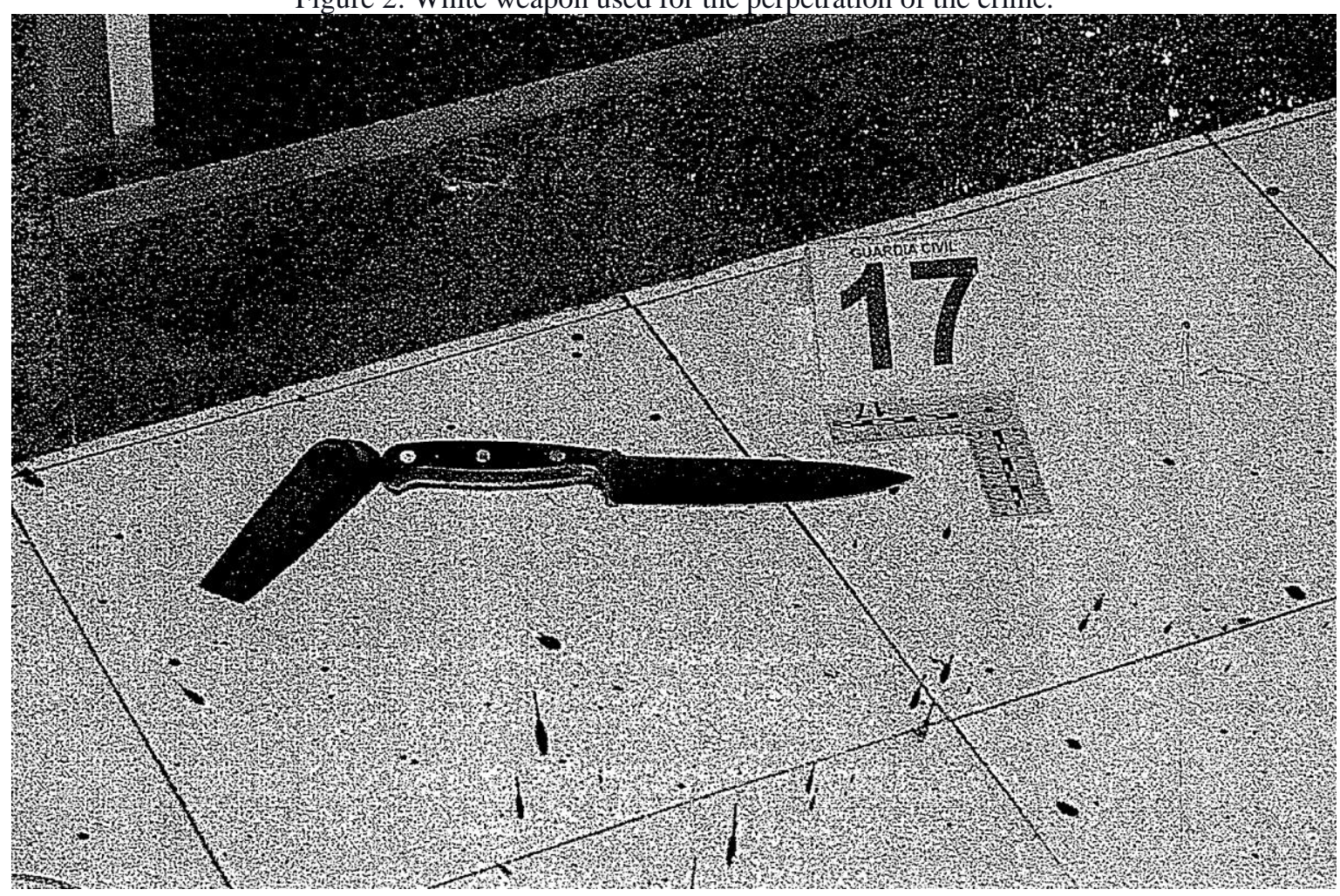




\section{RESULTS:}

For the development of the study of the informed person's personality, the following methodology was followed:

- Conducted clinical-expert interview (anamnesis) with the informed with a total investment of approximately 4-5 hours. in a Penitentiary Center of the Autonomous Community of Madrid.

- Updated administration of psychometric tests in order to assess their mental and psychopathological state (MCMI-3; PAI; 16PF; Salamanca Questionnaire for Personality Disorders; STAI; BIS-11; Davidson Trauma Scale-DTS- and SIMS.

- $\quad$ Analysis of the clinical and legal documentation provided.

As a result of the administration of the psychopathological questionnaires and the conducted clinical interview, the results obtained suggest that the informed presents:

- $\quad$ Absence of Serious and/or Severe Mental Disorder (neither past nor active).

- $\quad$ Presence of Personality Disorder.

- $\quad$ Presence of serious dysfunctional Personality traits of emotional instability (Borderline) on a paranoid, anankastic-obsessive and dependent basis.

- Simulation index (SIMS) not significant, so it follows that their degree of sincerity and reliability is normal and according to their socio-cultural and intellectual level.

In addition, an obsessive-anxious state was seen that is compatible with a:

- $\quad$ Mixed Anxious-Depressive Adaptive Disorder (code F43.22 of the ICD-10), circumscribed to the juridical-legal cause for which it is subjected and with a residual traumatic component derived from its pathobiography (Tiffon, 2016).

\section{DISCUSSION / CONCLUSIONS:}

Regarding the reason for the consultation as requested whether or not he maintained his cognitive/volitional faculties at the time of perpetrating the facts, the following was concluded for the preparation of the psychological expert:

1. At the time of perpetrating the events, the person informed belonged to an elite military unit: Sniper expert in anti-terrorist objectives belonging to the Army Corps of La Legión and trained in "hand-tohand fighting" training. 
A professional field which supposed to the informed person, and in the exercise of his functions, being engaged in official missions and assignments of high military responsibility and with high risk to his physical integrity, and which, in current times, refers to "feeling traumatized" by the object of some missions that he was entrusted with, even killing civilians (including children and women).

2. The entire set of information collected on the reported person's pathobiography, and depending on what was clinically explored by the undersigned Expert, at the time of perpetrating the alleged facts, everything could be compatible with the fact that the referred person presented an acute and critical psycho-emotional alteration moment prior to the commission of the event, as a result of the precursor events that he experienced as damaging to his person and physical integrity (such as the victim "came back with a knife and he put his right hand to defend himself and that man wanted to nail it in the head", (...)" that the victim came from the front, put the knife on his head and wanted to cut from top to bottom", according to the statement of the detainee before the $\mathrm{SS}^{\mathrm{a}}$.

This led him to experience a harmful excitement and impulsiveness typical of aggressive or hostile paranoid exacerbation (Cluster A and B personality traits) and also, as a result of his professional activity as an elite military man, to suffer a short-lived alteration of his awareness and critical capacity intense enough to break the inhibitory mechanisms of his behavior, and to behaviorally manifest in a highly harmful way in which it resulted, not being able to assess -in those precise moments- the scope of the fatal consequences that it supposed the perpetration of that harmful action.

3. In the absence of psychopathology or major mental disorder, we understand that the informed person could have suffered, as a consequence of the exacerbation of the paranoid traits previously exposed, a sudden and acute alteration of the mood and emotions that gave rise to the impulsive behavioral explosion, a sudden and immediate alteration of a high degree of aggressiveness caused by the circumstance that trigged the facts that are prosecuted, causing a decrease in cognitive-reflective capacities, and influencing harmful and negatively in the volitional of his behavior and the consequences that it entails. 


\section{REFERENCES}

- Tiffon, B.-N. “Archivos Delictivo-Criminológicos” (2016). Bosch Editor. Barcelona.

- Tiffon, B.-N. y cols. (2017). “Atlas de Psicología Forense (Penal)”. J.M. Bosch Editor. Barcelona.

- Tiffon, B.-N. y cols. (2019). “Atlas Práctico-Criminológico de Psicometría Forense (Volumen I): Asesinatos”. J.M. Bosch Editor. Barcelona.

- Tiffon, B.-N. y cols. (2019). “Atlas Práctico-Criminológico de Psicometría Forense (Volumen II): Tentativas de Asesinatos”. J.M. Bosch Editor. Barcelona.

- Tiffon, B.-N. (2021). "Criminal and Forensic Psychology of a Case of Filicide by Decapitation of a Minor". Journal of Forensic Medicine. ISSN: 2472-1026. Volume 6:3, 2021.

- Tiffon, B.-N. y González-Fernández, J. (2021). "Amok Syndrome. Qualified perspectives on an agressive reaction of pathological impulsiveness in the perpetration of a double crime with a firearm". Asean Journal of Psychiatry. Vol. 22(S2), June 2021: 1-5.

- Tiffon BN. "Atlas of Forensic Criminal Psychology". Taylor \& Francis Group-CRC Press. USA. In press. 2021. 